\title{
Characterization of bacterial communities associated with the pinewood nematode insect vector Monochamus alternatus Hope and the host tree Pinus massoniana
}

\author{
Yajie Guo ${ }^{1,2,3}$, Qiannan Lin ${ }^{1,2}$, Lyuyi Chen ${ }^{4}$, Rebeca Carballar-Lejarazú ${ }^{5}$, Aishan Zhang ${ }^{3}$, Ensi Shao ${ }^{3}$,
} Guanghong Liang ${ }^{1,2}$, Xia Hu ${ }^{1,2}$, Rong Wang ${ }^{1,2}$, Lei $X^{6}{ }^{6}$, Feiping Zhang ${ }^{1,2^{*}}$ and Songqing $\mathrm{Wu}^{1,2,3^{*}}$ (D)

\begin{abstract}
Background: Monochamus alternatus Hope is one of the insect vectors of pinewood nematode (Bursaphelenchus xylophilus), which causes the destructive pine wilt disease. The microorganisms within the ecosystem, comprising plants, their environment, and insect vectors, form complex networks. This study presents a systematic analysis of the bacterial microbiota in the M. alternatus midgut and its habitat niche.

Methods: Total DNA was extracted from 20 types of samples (with three replicates each) from M. alternatus and various tissues of healthy and infected $P$. massoniana (pines). $16 \mathrm{~S}$ rDNA amplicon sequencing was conducted to determine the composition and diversity of the bacterial microbiota in each sample. Moreover, the relative abundances of bacteria in the midgut of $M$. alternatus larvae were verified by counting the colony-forming units.

Results: Pinewood nematode infection increased the microbial diversity in pines. Bradyrhizobium, Burkholderia, Dyella, Mycobacterium, and Mucilaginibacter were the dominant bacterial genera in the soil and infected pines. These results indicate that the bacterial community in infected pines may be associated with the soil microbiota. Interestingly, the abundance of the genus Gryllotalpicola was highest in the bark of infected pines. The genus Cellulomonas was not found in the midgut of M. alternatus, but it peaked in the phloem of infected pines, followed by the phloem of heathy pines. Moreover, the genus Serratia was not only present in the habitat niche, but it was also enriched in the $M$. alternatus midgut. The colony-forming unit assays showed that the relative abundance of Serratia sp. peaked in the midgut of instar II larvae (81\%).

Conclusions: Overall, the results indicate that the bacterial microbiota in the soil and in infected pines are correlated. The Gryllotalpicola sp. and Cellulomonas sp. are potential microbial markers of pine wilt disease. Additionally, Serratia sp. could be an ideal agent for expressing insecticidal protein in the insect midgut by genetic engineering, which represents a new use of microbes to control M. alternatus.
\end{abstract}

Keywords: Monochamus alternatus Hope, Pinus massoniana, Microbial community, 16S rDNA, Diversity analysis

\footnotetext{
*Correspondence: fpzhang1@163.com; dabinyang@126.com

${ }^{1}$ College of Forestry, Fujian Agriculture and Forestry University, Fuzhou 350000, China

Full list of author information is available at the end of the article
}

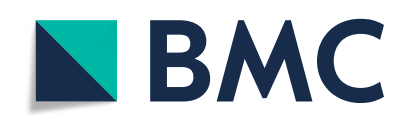

(- The Author(s). 2020 Open Access This article is licensed under a Creative Commons Attribution 4.0 International License, which permits use, sharing, adaptation, distribution and reproduction in any medium or format, as long as you give appropriate credit to the original author(s) and the source, provide a link to the Creative Commons licence, and indicate if changes were made. The images or other third party material in this article are included in the article's Creative Commons licence, unless indicated otherwise in a credit line to the material. If material is not included in the article's Creative Commons licence and your intended use is not permitted by statutory regulation or exceeds the permitted use, you will need to obtain permission directly from the copyright holder. To view a copy of this licence, visit http://creativecommons.org/licenses/by/4.0/. The Creative Commons Public Domain Dedication waiver (http://creativecommons.org/publicdomain/zero/1.0/) applies to the data made available in this article, unless otherwise stated in a credit line to the data. 


\section{Background}

Pine wilt disease is a destructive disease of pine trees caused by the pinewood nematode, Bursaphelenchus xylophilus (Steiner \& Buhrer) Nickle, which causes significant environmental and economic losses worldwide [1]. It originated in North America and then spread to Asia and Europe [2, 3]. In Japan, pine wilt disease has threatened pine forests since 1905, with the loss of 700 , $000 \mathrm{~m}^{3}$ of pine trees each year [3, 4]. In China, since the discovery of pinewood nematode in Nanjing in 1982, the disease has spread rapidly, threatening the safety of nearly 60 million hectares of pine trees. In Asia, pinewood nematode infection mainly occurs during feeding and oviposition of adults of the beetle species known as Monochamus alternatus Hope, which spreads the disease among pine trees $[5,6]$. Therefore, effective prevention and control of $M$. alternatus populations are one of the best approaches to control pine wilt disease.

Microbial insecticides, the most widely used biological control method, have not been well developed for controlling wood-boring insects such as M. alternatus [710]. The main problem to overcome is that it is difficult for the insecticidal protein to enter the tree trunk to reach the $M$. alternatus larvae [7-10]. However, research has shown that mosquitoes can become resistant to malaria infection as a result of colonization by symbiotic bacteria carrying antimalaria effector molecules to the mosquito midgut lumen [11]. A study has shown that a strain of Serratia bacteria (AS1) can colonize the mosquito midgut and inhibit the growth of the malaria parasite Plasmodium falciparum in mosquitos [12]. Therefore, the purpose of this study was to identify a bacterial species that is present in the habitat niche and is enriched in the midgut of $M$. alternatus larvae, as this species could potentially be used as a carrier of an insecticidal protein that is toxic to $M$. alternatus larvae.

The microbiomes in plants, insects and soil make up an aboveground-belowground microbiota environment, it has become a hotspot to study the role of changes in these microbiomes in theses interactions [13-15]. Many studies have investigated the associations between the bacterial communities of pinewood nematode, pine trees, and insect vectors, including various instars of $M$. alternatus [16]; M. alternatus and M. galloprovincialis adults [17, 18]; M. galloprovincialis and pinewood nematode [1, 19-27]; Pinus trees [28-31]; pinewood nematode and infected Pinus trees [32, 33]; pinewood nematode, infected Pinus pinaster trees, and the vector M. galloprovincialis [34]; and the soil of infected Pinus trees [35]. However, few studies have analyzed the associations between the bacterial communities of the insect vector $M$. alternatus, host tree $P$. massoniana (pines), and soil.
In this study, $M$. alternatus, pines, and soil were systematically sampled from the same location during the same time period. The compositions of each microbiota in the $M$. alternatus midgut and its habitat niche were analyzed by $16 \mathrm{~S}$ rDNA amplicon sequencing. The bacterial communities associated with $M$. alternatus and pines were characterized. The relative abundance of a bacterial species of interest (Serratia sp.) in the various instar larvae were verified by conducting colony-forming unit assays. The results contribute to the understanding of the differences among the microbiomes of M. alternatus and its habitat niche.

\section{Results}

Operational taxonomic unit (OTU) sequencing results

A total of 9174 OTUs were obtained from the 60 samples of $M$. alternatus and its habitat niche. According to the rarefaction curves, the number of sequences obtained was able to reflect the main bacterial information in each sample (Additional file 1: Figure S1). There were 1573 OTUs shared among all samples. 1778 and 1922 unique OTUs were detected in samples from healthy and infected pines, respectively. Only 195 unique OTUs were found in samples from M. alternatus (Fig. 1a). Instar II larvae feed on phloem, and the number of OTUs shared by the instar II larvae midgut and the phloem of infected pine (346) was close to the number shared by instar II larvae midgut and the phloem of healthy pine (325) (Fig. 1b). Instar III larvae feed on xylem, and the number of OTUs shared by instar III larvae midgut and the xylem of infected pine (233) was approximately twice that shared by instar III larvae midgut and the xylem of healthy pine (114). There were 1328 unique OTUs in the xylem of infected pines, which was far more than the 237 unique OTUs in the xylem of healthy pines (Fig. 1c). There were 84 shared OTUs in the samples from midgut of adult M. alternatus, healthy pine bark, and infected pine bark. The number of unique OTUs (not found in the adult $M$. alternatus) in infected pine bark was about 2.5 times that in healthy pine bark (Fig. 1d).

\section{Linear discriminant analysis effect size (LEfSe) analysis}

Species distribution analysis at the phylum level indicated that the main bacteria in the $M$. alternatus midgut belonged to Proteobacteria and Firmicutes. Infected pines mainly harbored Bacteroidetes, Armatimonadetes, Actinobacteria, Acidobacteria, and Proteobacteria (Additional file 1: Figure S2). The Acidobacteria in infected pines was highly similar to that in healthy pines, while the Proteobacteria in infected pines was highly similar to that in the midgut of $M$. alternatus (Fig. 2). 


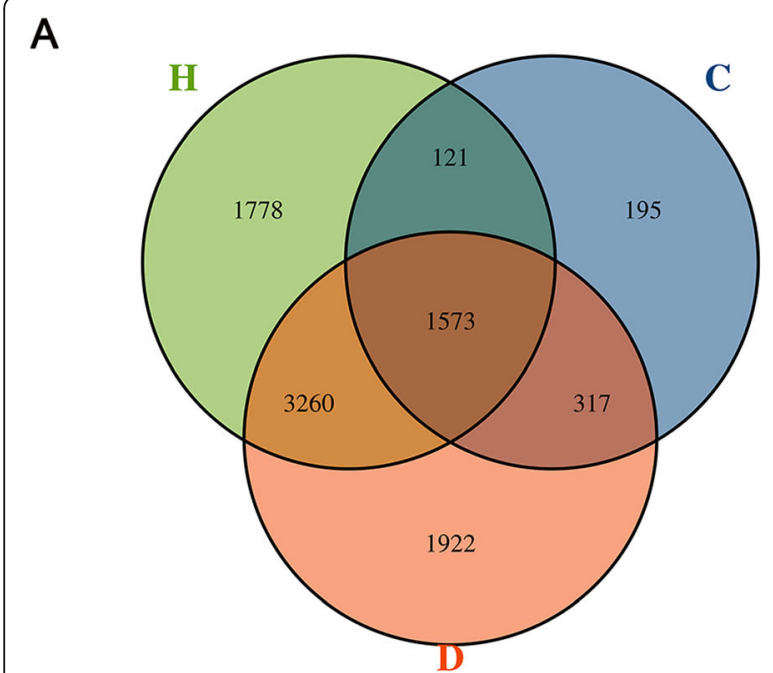

B

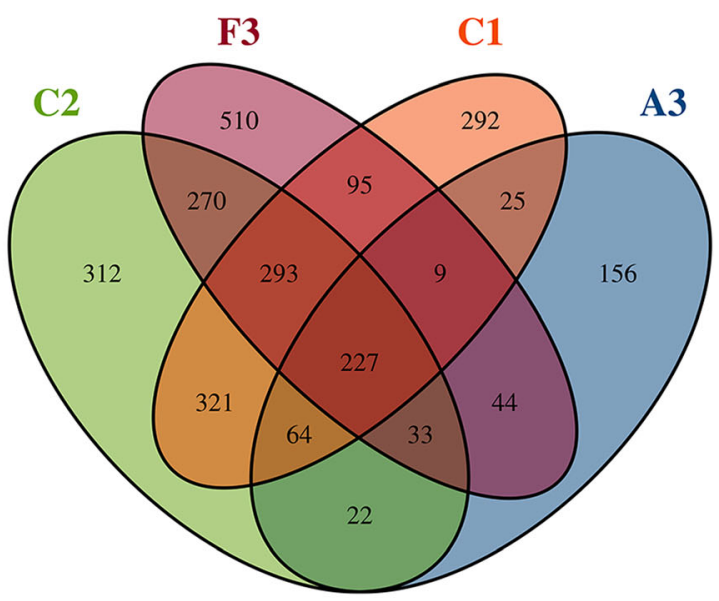

C
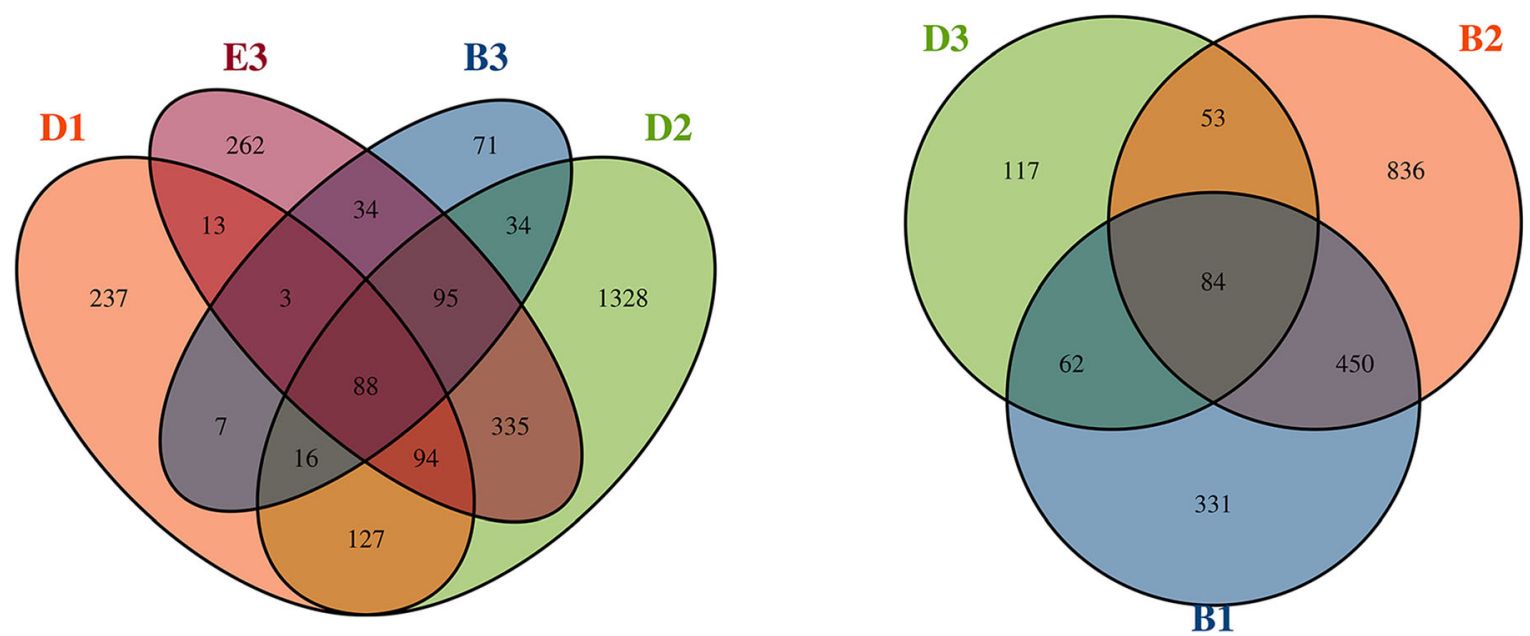

Fig. 1 Operational taxonomic unit (OTU) Venn diagrams. (a) H: healthy pine (Pinus massoniana) and soil, D: infected pine and soil, C: Monochamus alternatus and frass; (b) A3: instar II larvae midgut, C1: healthy pine phloem, C2: infected pine phloem, F3: instar II larvae frass; (c) B3: instar III larvae midgut, D1: healthy pine xylem, D2: infected pine xylem, E3: instar III larvae frass. (d) D3: adult midgut, B1: healthy pine bark, B2: infected pine bark

\section{Bacterial community compositions in M. alternatus and its} habitat niche

There were significant differences in species composition between infected and healthy pines. The Streptophyta of Cyanobacteria/Chloroplast was the dominant in healthy pines, due to the V3-V4 region cannot distinguish $16 \mathrm{~s}$ rDNA from bacteria and Cyanobacteria/Chloroplast. Regarding the infected pines, the most abundant genera were Sphingomonas (7.66\%), followed by Burkholderia (6.51\%) and Acidobacteria subgroup 1 (Gp1) (6.51\%). In the midgut and frass of $M$. alternatus, the most abundant genera were Serratia (25.25\%), Enterobacter (12.42\%), Halotalea (8.81\%), and Stenotrophomonas (6.68\%). The relative abundance of Acidobacteria subgroup 1 (Gp1), subgroup 2 (Gp2), and subgroup 3 (Gp3) in surface soil and rhizosphere soil exceeded 50\%, with no differences between infected and healthy pines (Fig. 3) (Additional file 1: Figures S3, S4).

Regarding the frass of different stages of $M$. alternatus after feeding, Granulicella was the most abundant genus (12.15\%) in the frass of instar II larvae, followed by genus Sphingomonas (10.11\%). Saccharibacteria was the most abundant genus in the frass of instar III larvae (12.57\%), followed by genus Burkholderia (11.68\%). The relative abundance of genus Pseudoxanthomonas (5.31\%) in the frass of instar III larvae was higher than in the frass of instar II larvae and the midgut of various instars (total: 0.03\%) (Fig. 3 and Additional file 1: Figures S5, S6). 


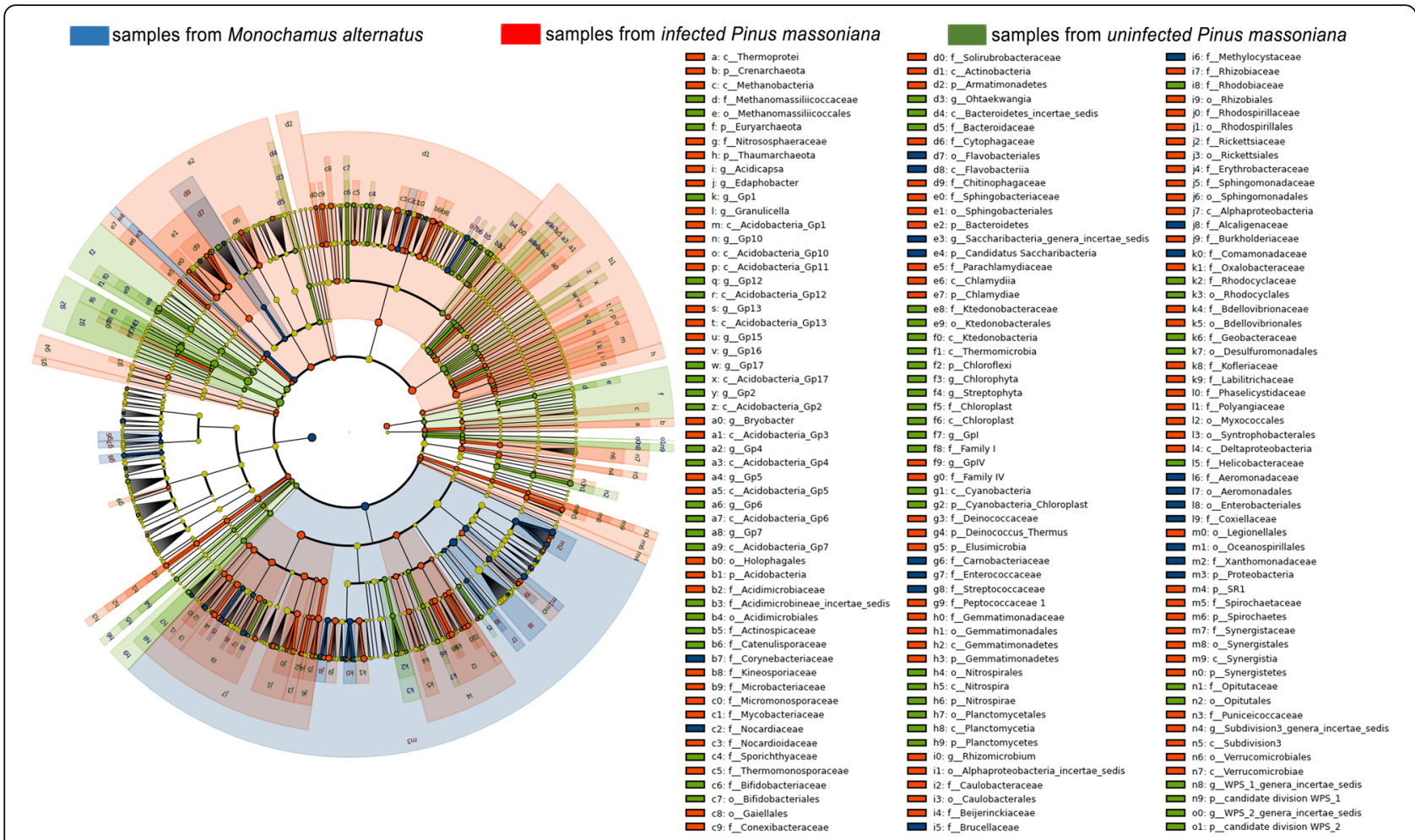

Fig. 2 Cladogram of bacteria from Monochamus alternatus and infected and healthy Pinus massoniana. Different colors represent different bacterial groups, and nodes of different colors represent the bacteria that play important roles in each group, i.e., blue, red, and green nodes represent the bacteria that play important roles in samples from M. alternatus, infected P. massoniana, and healthy P. massoniana, respectively, while the yellow nodes represent bacteria that do not play important roles

After feeding by $M$. alternatus adults, the most abundant genera in the bark from infected pines were Sphingomonas and Granulicella (Additional file 1: Figure S7). The bark, phloem, and xylem of infected pines contained more putative pathogenic bacteria (mainly Saccharibacteria, Burkholderia, and Granulicella) than the corresponding tissues in healthy pines (Fig. 3). These results indicate that the dominant bacteria were similar between the frass of larvae and infected pines.

\section{Specific bacterial genera in the habitat niche of $M$. alternatus}

The heatmap shows that genera Escherichia/Shigella, Pseudomonas, and Spartobacteria were mainly distributed in pines, and their overall level was constant in healthy and infected pines (Fig. 4, labeled green). Several bacterial genera were mainly found in the infected pines and soil of healthy pines, including Dyella, Burkholderia, Bradyrhizobium, Mycobacterium, and Mucilaginibacter (Fig. 4, labeled pink). The genera Rhizobium, Terriglobus, Nocardioides, and Saccharibacteria were mainly found in infected pines and the phloem of healthy pines (Fig. 4, labeled light blue). In addition, the genus Pseudoxanthomonas was mostly distributed in the phloem and root of healthy pines ( $14 \%$ in both tissues) and infected pines
(39\% and 2.56\%, respectively) (Fig. 4, labeled light blue). Granulicella and Sphingomonas genera were mainly distributed in the bark of healthy pines compared to the other health pine tissues, and their relative abundances were increased in all infected pines tissues (Fig. 4, labeled yellow). The genus Gryllotalpicola was only found in the phloem $(0.1 \%)$ of healthy pines (rather than any other of the healthy pine tissues), but it was increased in the bark (4.1\%), phloem (3.1\%), xylem (1.6\%) and root $(0.6 \%)$ in infected pines, and was also found with low relative abundance in the midgut and frass of $M$. alternatus (Fig. 4, labeled orange). Interestingly, the genus Cellulomonas was not found in the midgut of $M$. alternatus, and the highest relative abundance occurred in the phloem of infected pines $(2.9 \%)$, followed by the phloem of healthy $M$. alternatus (0.8\%). Its relative abundance was also low $(<0.01 \%)$ in the needle, root, and surface soil of healthy pines, as well as in the needle, bark, xylem, root, surface soil, and rhizosphere soil of infected pines (Fig. 4, labeled blue).

\section{Specific bacterial genera in the midgut of $M$. alternatus}

The bacterial genera Serratia, Enterobacter, Achromobacter, and Stenotrophomonas were dominant in the midgut of M. alternatus (Fig. 4, labeled red). Serratia 


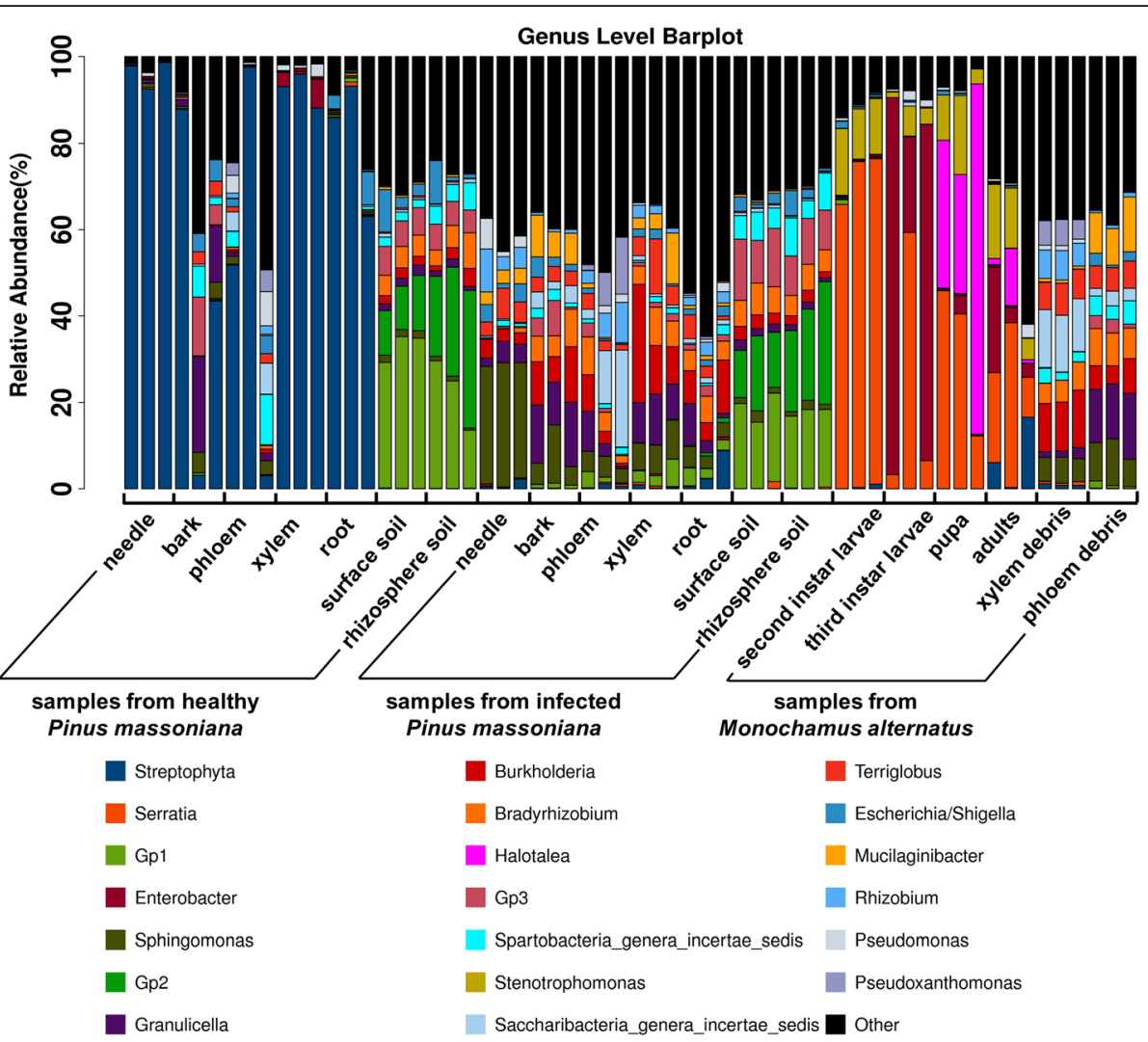

Fig. 3 Stacked bar plot of bacterial genera from Monochamus alternatus and infected and healthy Pinus massoniana. The 20 most abundant OTUs are shown, with the remaining grouped together in the group labeled "other"

was the most abundant bacterial genus in the midgut of instar II larvae. Enterobacter was the most abundant genus in the midgut of instar III larvae (65\%), and it was also highly abundant in the midgut of adult insects (10.30\%). Halotalea was the most abundant bacterial genus in the pupae midgut (47.69\%) (Fig. 5a).

Interestingly, the relative abundance of genus Serratia was different in various instars of $M$. alternatus. In the habitat niche, Serratia was detected in all samples, but with low relative abundance $(<0.5 \%)$. However, Serratia was enriched in the midgut of $M$. alternatus larvae; it peaked at $72.11 \%$ in the instar II larvae, decreased in the instar III larvae $(23.46 \%)$, increased again in the pupae $(32.85 \%)$, and was lowest in adults $(22.71 \%)$. Additionally, Serratia was found in the frass of the instar II and III larvae $(<0.6 \%)$. These results indicate a close relationship between genus Serratia and M. alternatus (Fig. 5b).

The colony-forming unit assays showed that Serratia sp. was present in midgut of instars I-V regarding both $M$. alternatus reared on an artificial diet and wildcaught M. alternatus. Serratia sp. peaked in instar II (about $81 \%$ in both), was at a minimum in instar III ( $9 \%$ in the larvae reared on the artificial diet and $11 \%$ in the wild-caught larvae), and was relatively stable for instars I and IV between the reared on artificial diet and wildcaught groups. However, in instar V (diapause), Serratia sp. in larvae reared on the artificial diet was higher than in wild-caught larvae (Fig. $5 \mathrm{c}$ and d). The results suggest that food has little effect on the relative abundance of Serratia sp. in the midgut of $M$. alternatus larvae, but further research is needed on its abundance pattern and whether it is related to the larval metabolic mechanisms.

The heatmap of Spearman's rank correlation coefficients at the genus level shows that the relative abundance of Serratia was positively correlated with Stenotrophomonas, Gryllotalpicola, and Pseudoxanthomonas, and negatively correlated with Gp1 Gp2 Gp3, Escherichia/Shigella, Burkholderia. Bradyrhizobium, Sphingomonas, Granulicella, and Mucilaginibacter (Additional file 1: Figure S8).

\section{Discussion}

This study provides a systematic description of the microbial communities in the midgut of $M$. alternatus and its habitat niche based on $16 \mathrm{~S}$ rDNA gene amplicon sequencing. Samples were collected during the same time period from the same pine stand to ensure the stability of the microbial composition. And the results of 


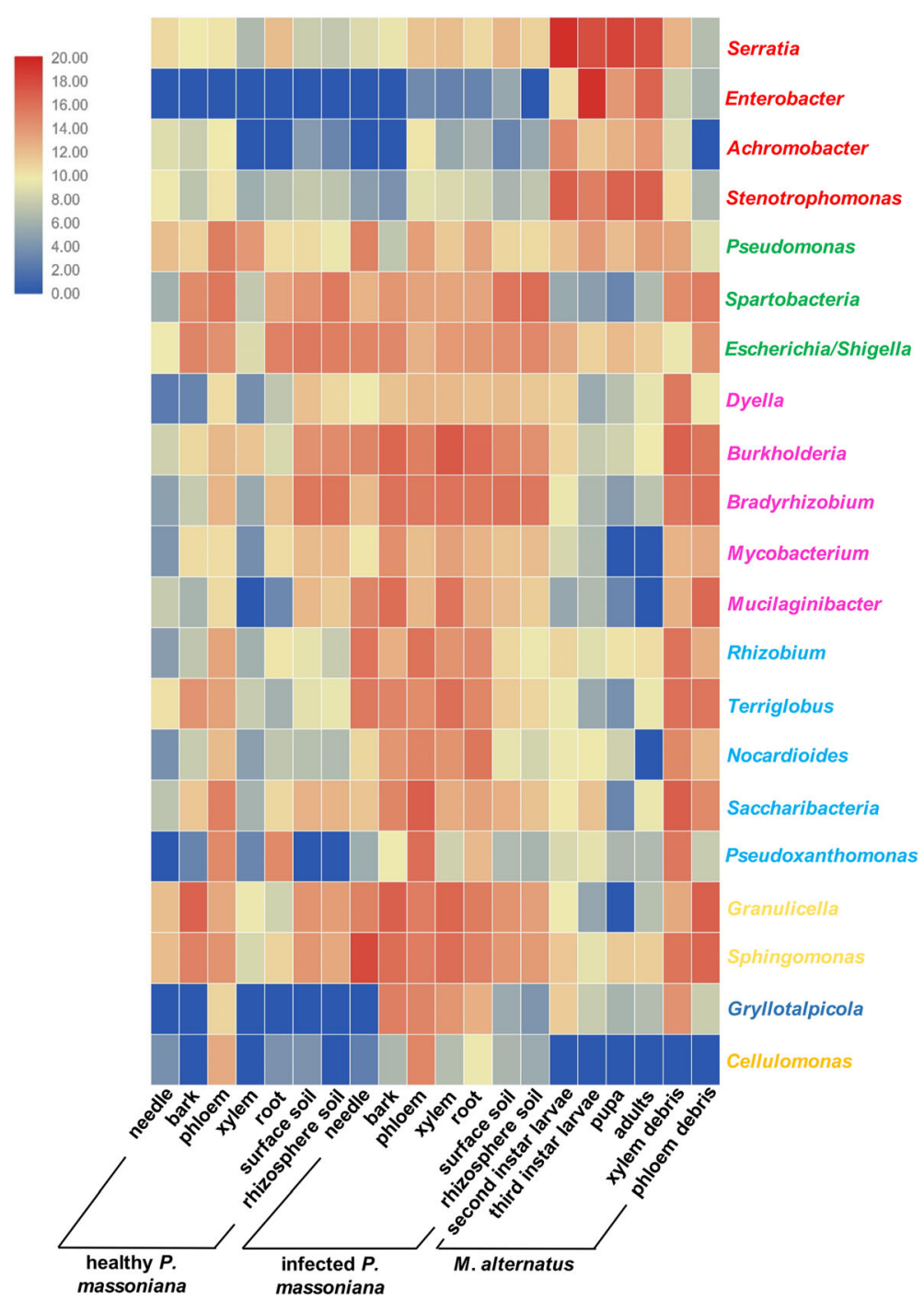

Fig. 4 Heatmap of bacterial genera in all samples from Monochamus alternatus and infected and healthy Pinus massoniana. The red genera were mainly abundant in the M. alternatus midgut. The green genera were equally abundant in healthy and infected $P$. massoniana. The pink genera were abundant in the soil of healthy P. massoniana and various tissues of infected $P$. massoniana. The light blue genera were abundant in the phloem of healthy $P$. massoniana and various tissues of infected $P$. massoniana. The yellow genera were abundant in the bark of healthy $P$. massoniana and various tissues of infected P. massoniana. The dark blue genus was mainly present in the bark, phloem, xylem, and root of infected $P$. massoniana. The orange genus was mainly present in the phloem of $P$. massoniana, and it was more abundant in infected pines than healthy pines

rarefaction curves analysis of all samples showed sampling sufficiency.

Soil microbiomes exhibit extremely rich diversity and research shows that plants and insect microbiomes depend on soil microbiomes [14]. Acidobacteria is one of the most dominant phyla in the soil [36], and it was the predominant bacterial phyla in the surface soil and rhizosphere soil of both healthy and infected pines in this study (including Gp1, Gp2, and Gp3). Many studies have shown that Acidobacteria plays a vital role in the ecosystem, and it has a rich diversity of metabolic and genetic functions [37], as well as making a significant contribution to ecological stability [38]. Acidobacteria are the dominant bacteria in most soils because its optimum $\mathrm{pH}$ is low [39], though different subgroups of Acidobacteria have different optimum $\mathrm{pH}$ values. For example, the subgroup Gp1 grows best in soil environments with a $\mathrm{pH}$ of $4-5.5[40,41]$. Shi et al. found that pinewood nematode infection changes the physical and chemical properties of the soil and the bacterial community composition and diversity; however, Acidobacteria was the predominant bacteria in nematode-infected soil, which had a lower $\mathrm{pH}$ than the uninfected soil [35]. 


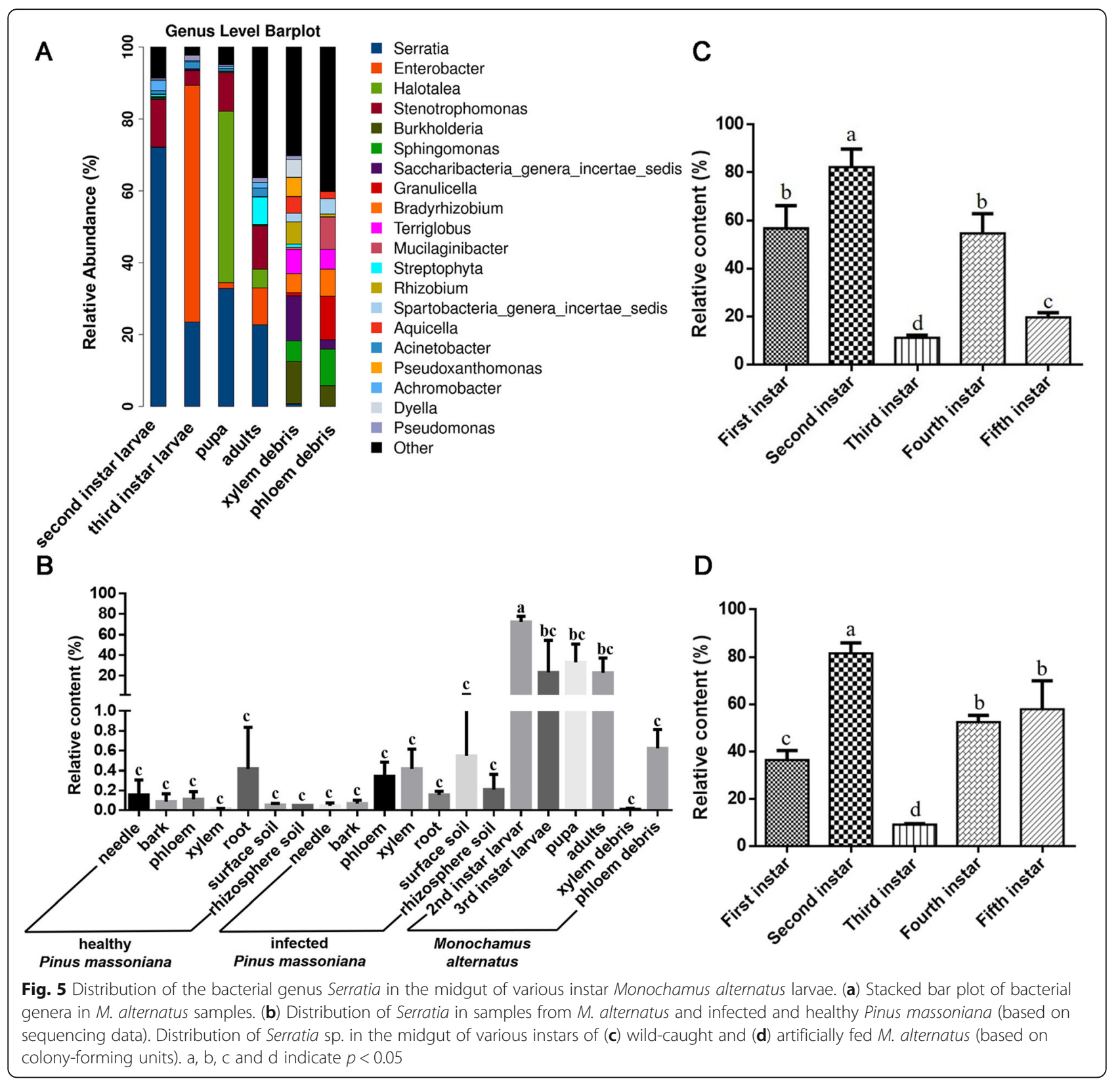

Additionally, the soil and infected pines shared multiple bacterial genera. Bradyrhizobium, Burkholderia, Dyella, Mycobacterium, and Mucilaginibacter were the predominant bacterial genera in infected pines and the soil of healthy pines. Among them, only genus Bradyrhizobium was previously found in the soil of nematodeinfected and nematode-uninfected pines [35]. Additionally, studies in various countries have reported that genus Burkholderia is found on pinewood nematodes $[24,25,27]$.

Moreover, the dominant bacteria in pines changed significantly as a result of the damaged caused by pine wilt disease. The dominant bacterial genera in the infected pines are related to plant growth [42-46] and they can degrade compounds, especially cellulose [47-49]. It has been reported that cellulases played an important role during the nematode progressing inside the plant host $[27,50]$. Therefore, the dominant bacterial genera were present in all samples from infected pines, but only a few were found in the midgut of $M$. alternatus and healthy pines. Among them, Rhizobium, Saccharibacteria, Terriglobus, Nocardioides, and Pseudoxanthomonas were only found in the phloem of healthy pines. Additionally, Granulicella and Sphingomonas were the main genera in the bark of healthy pines. Previous studies reported that the genera Pseudomonas and Pantoea and the orders Xanthomonadales, 
Acidobacteriales, and Rhizobiales are associated with Pinus spp. [28, 32, 51], and Sphingomonadales was found in both $P$. pinaster and M. alternatus [34]. These results indicate the systemic distributions of bacteria in different versions of the habitat niche of $M$. alternatus.

It has been reported that the genus Gryllotalpicola was isolated from the midguts of Megopis sinica, M. alternatus, and Reticulitermes speratus, while the genus Cellulomonas was isolated from both the midgut and hindgut of M. sinica and M. alternatus [52, 53] and from the stem of $P$. contorta and the needles of Thuja plicata [29]. In this study, however, Gryllotalpicola had a relative abundance of only $0.25 \%$ in the midgut of $M$. alternatus, and Cellulomonas was not found in the midgut of M. alternatus. Both Gryllotalpicola and Cellulomonas can degrade cellulose [52], which is the main nutrient component in the food of wood-boring insects and plays an important role in the growth and development of pests [54]. Therefore, Gryllotalpicola sp. is a potential cellulolytic bacterial species that may promote the feeding of M. alternatus on infected pines. Moreover, many soil microorganisms have been used as indicators of soil quality, particularly microorganisms that are resistant to heavy metals and toxic chemicals $[55,56]$. Therefore, according to their distribution in infected pines, Gryllotalpicola spp. and Cellulomonas app. Could as potential microbial markers of pine wilt disease in pines.

There is a strong association among Serratia sp., $M$. alternatus, and pinewood nematode. Serratia spp. has been isolated from Pinus spp. and pinewood nematode in various countries [23, 25-27, 32, 51, 57]. Serratia sp. has been shown to be present at a high density in the bacterial community of the thorax (44\%) and abdomen (95\%) of $M$. galloprovincialis adults $[17,18]$. In this study, however, the relative abundance of Serratia in the midgut of adults (22\%) was lower than the relative abundances reported for the thorax and abdomen in previous research, which may be related to the different Monochamus species investigated and the different durations since emerging as adults. Notably, in this study, Serratia sp. was found in the midgut of larvae and pupa, at $81 \%$ in the midgut of instar II larvae. Serratia spp. has strong stability for rapid adaptation to the environment $[58,59]$. S. marcescens PWN146 has been shown to be able to colonize plants [33]. As Serratia sp. was present in the habitat niche and enriched in the midgut of M. alternatus in this study, Serratia sp. (carrying toxins) will likely be able to enter M. alternatus larvae.

Additionally, S. marcescens has multiple roles after colonizing plants. Under environmental stimulation, it can change from a beneficial bacteria (promoting plant growth) to a plant pathogen $[60,61]$. Also, Serratia sp. A88copa13 encodes extracellular serralysin and serine proteases [62] and Serratia sp. associated with the pinewood nematode can degrade cellulose, which is beneficial for colonization of wood tissues [26]. Moreover, Serratia sp., which in the gut of Dendroctonus armandi larvae and $M$. alternatus larvae, secretes cellulase and other extracellular enzymes [63, 64]. The main enzymes involved in cellulose depolymerization are endoglucanase, exoglucanase, and $\beta$-glucosidase $[65,66]$. Many endoglucanases from Serratia spp. have been annotated [67-69], and Serratia spp. can synthesize $\beta$ xylosidase and lignins [64, 70]. Thus, Serratia sp. may be a cellulolytic and hemicellulolytic bacteria that can survive in the midgut of $M$. alternatus and its habitat niche.

As mentioned earlier, the main problem associated with using microbial insecticides to control $M$. alternatus is that it is difficult for the insecticides to enter the tree trunk and reach the $M$. alternatus larvae [7-10]. In this study, as an environmental microorganism, the genus Serratia was not only present in the healthy pines and soil but it was also enriched in the midgut of M. alternatus as a predominant symbiotic bacterial genus. Therefore, genetically engineered Serratia sp. could be an ideal agent for expressing insecticidal protein in M. alternatus midguts, which would represent a new use of microbes to control $M$. alternatus. Furthermore, the cellulose-degrading bacterial genera Stenotrophomonas, Gryllotalpicola, and Pseudoxanthomonas $[49,52]$ were positively correlated with Serratia. In contrast, the genera Gp1, Gp2, Gp3, Saccharibacteria, Escherichia/Shigella, Bradyrhizobium, Sphingomonas, Terriglobus, Burkholderia, and Mucilaginibacter were negatively correlated with Serratia, and they are associated with soil $\mathrm{pH}$, plant growth, and cellulose degradation $[39,42,44,45]$. These bacterial genera provide possible tools for regulating the abundance of Serratia sp. in the habitat niche of $M$. alternatus.

\section{Conclusions}

This study indicates that the bacterial diversity was significantly increased in infected pines compared to healthy pines. The bacteria detected in this study might play a role in the soil-pines-M. alternatus system. Bradyrhizobium, Burkholderia, Dyella, Mycobacterium, and Mucilaginibacter were dominant bacterial genera in soil and infected pines; Gryllotalpicola and Cellulomonas were predominant genera in infected pines; and the genus Serratia was present in the habitat niche and was enriched in the midgut of M. alternatus (Fig. 6). Systematic analysis of the microbiomes in M. alternatus and its habitat niche is important not only to better understand the role of bacteria in pine wilt disease but also to provide a new strategy for the control of pine wilt disease.

\section{Methods}

\section{Sample collection}

All samples were collected from a pine stand $\left(26^{\circ} 9^{\prime}\right.$ $1.6^{\prime \prime} \mathrm{N}, 119^{\circ} 35^{\prime} 33^{\prime \prime}$ E) in Guantou city, Lianjiang 


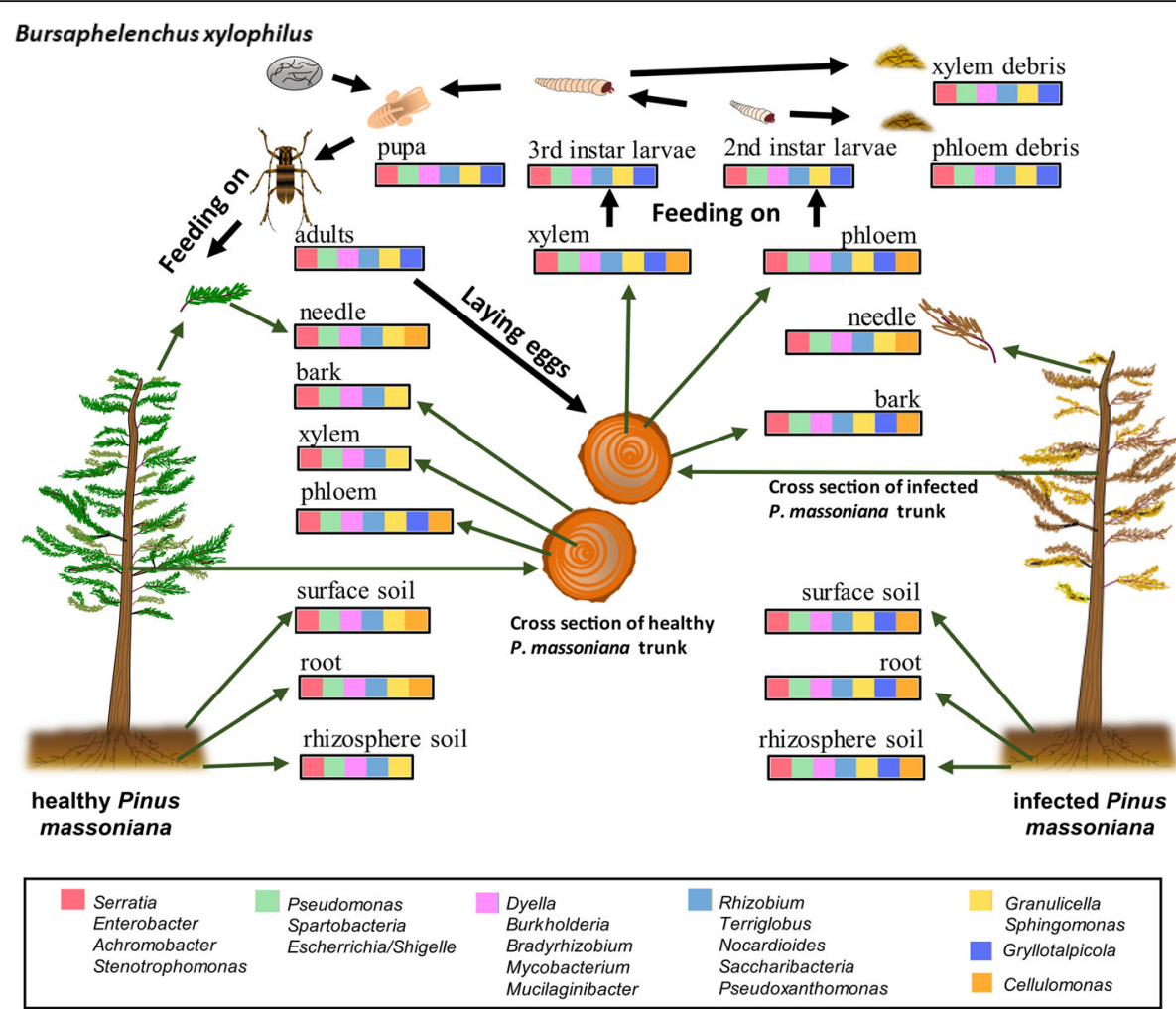

Fig. 6 Changes in the distribution of major bacterial groups during the transmission of pinewood nematode by Monochamus alternatus. The bacteria are classified into seven color-coded groups according to their distribution in the various samples, as explained in the legend of Fig. 4

county, Fujian province, China. The P. massoniana (pines) were 25 years old and had not been damaged by other diseases or insects besides pine wilt disease. To determine whether the trees were infected with pinewood nematode, their trunks were cut into cross-sections to assess the presence of $M$. alternatus or other insects, and the Baermann funnel method followed by polymerase chain reaction (PCR) with specific primers was then used to confirm the presence of the pinewood nematode [71]. Thereafter, three healthy and three infected pine trees $(10 \mathrm{~m}$ away from each other) were selected. For both the infected and healthy pines, secondary branches were sampled, which involved collecting needles, bark, phloem, and xylem. Regarding the surface soil, rhizosphere soil, and roots, samples were obtained from points in the same direction as the sampled secondary branches of the infected and healthy pines. After removing leaves and roots from the surface soil, soil samples were collected at each sampling point with a soil auger at a depth of $0-5 \mathrm{~cm}$ (for surface soil) and a depth of $5-15 \mathrm{~cm}$ (for rhizosphere soil). Roots samples were isolated from the rhizosphere soils. Samples (with three replicates for each samples type) were placed in separate sterile plastic containers. Next, three instar II larvae, three instar III larvae, and three pupae were collected from the logs, which had the entry-points of $M$. alternatus, obtained from three infected pines. The $M$. alternatus instars were determined by head capsule width $[72,73]$. Thereafter, other logs obtained from the infected trees were placed in cages near the sampling points and a single $M$. alternatus adult was obtained as it emerged from the log at each sampling point. The instar II and III larvae were maintained in a plastic box and their frass was also collected. All samples were placed in dry ice immediately after collection, brought back to the laboratory, and then stored at $-80^{\circ} \mathrm{C}$ until use.

\section{DNA extraction}

Microbial DNA was extracted from each sample by mechanical lysis in sodium dodecyl sulfate (SDS), followed by treatment with hexadecyl trimethyl ammonium bromide (CTAB) [74]. Pine samples $(1.0 \mathrm{~g})$ and soil samples $(0.3 \mathrm{~g})$ were homogenized with liquid nitrogen and mixed with $0.9 \mathrm{~mL}$ DNA extraction buffer $(100 \mathrm{mM}$ Tris- $\mathrm{HCl}$ [pH 8.0], $25 \mathrm{mM}$ sodium ethylenediaminetetraacetic acid [EDTA, pH 8.0], 10\% SDS, $0.5 \mathrm{M} \mathrm{NaCl}$, and $1 \% \mathrm{CTAB})$ and $5 \mu \mathrm{L}$ proteinase $\mathrm{K}(10 \mathrm{mg} / \mathrm{mL})$ in $1.5-\mathrm{mL}$ tubes followed by horizontal shaking at $230 \mathrm{rpm}$ for 30 min at $37^{\circ} \mathrm{C}$. Thereafter, $0.3 \mathrm{~mL}$ of $20 \%$ SDS was added, and the samples were incubated at $65^{\circ} \mathrm{C}$ for $2 \mathrm{~h}$ with gentle end-over-end inversion every $20 \mathrm{~min}$. The samples were frozen at $-70^{\circ} \mathrm{C}$ for $20 \mathrm{~min}$ and then 
incubated at $65^{\circ} \mathrm{C}$ for $20 \mathrm{~min}$, and this process was repeated three times. The samples were then centrifuged at $6000 \times \mathrm{g}$ for $10 \mathrm{~min}$ at $4{ }^{\circ} \mathrm{C}$ and the supernatants were transferred into 50-mL centrifuge tubes. Supernatants from two cycles of extractions were combined and mixed with an equal volume of phenol: chloroform: isoamyl alcohol (25:24:1, v/v/v). The aqueous phase was recovered after centrifugation, and DNA was precipitated using 0.1 volume of sodium acetate and 0.6 volume of isopropanol at room temperature for $1 \mathrm{~h}$. A DNA pellet was obtained by centrifugation at $14,000 \times \mathrm{g}$ for $30 \mathrm{~min}$ at room temperature, washed twice with cold $70 \%$ ethanol, and resuspended in sterile deionized water.

Each insect surface was sterilized with $70 \%$ ethanol for $1 \mathrm{~min}$, and then rinsed with sterile water. Midgut samples were dissected under a stereoscopic microscope and homogenized in $500 \mu \mathrm{L}$ Tris-EDTA (TE) buffer. Microbial DNA was extracted from each midgut sample using an E.Z.N.A. Bacteria DNA Kit (Omega Bio-Tek, Norcross, GA, USA). All DNA samples were stored at $20^{\circ} \mathrm{C}$ until further use.

\section{S rDNA gene amplicon sequencing}

The 16S rDNA gene was amplified using a KAPA HiFi Hotstart ReadyMix PCR kit (Kapa Biosystems, Boston, Massachusetts, USA) and the universal primers 341F/ 806R (341F: ACTCCTACGGGRSGCAGCAG, 806R: GGACTACVVGGGTATCTAATC) targeting the V3V4 region. PCR amplicons were purified using an AxyPrep DNA kit (Axygen Biosciences, Central Avenue, Union City, CA, USA) and quantified using a Qubit 2.0 Fluorometer (Thermo Fisher Scientific, Waltham, MA, USA). The DNA was pooled, with a final concentration of $10 \mathrm{ng} / \mu \mathrm{L}$. The quality of the amplicon libraries was assessed using a NanoDrop 2000 UV spectrophotometer (Thermo Fisher Scientific) and by agarose gel electrophoresis. The amplicon library sequencing was performed on an Illumina HiSeq PE250 platform (Illumina, San Diego, CA, USA) according to the standard protocols at RealBio Technology, Shanghai, China.

\section{Bioinformatics analysis}

The paired-end reads were merged into longer tags and quality filtered using PANDAseq to obtain high-quality tags [75]. Amplicon libraries were sequenced by pairedend reads of $425 \mathrm{bp}$. After quality control, OTUs were clustered with a similarity cutoff of $97 \%$ using Usearch [76]. The OTUs were further subjected to a taxonomybased analysis using the Ribosomal Database Project (RDP) algorithm and the Greengenes database (http:// greengenes.lbl.gov) [77]. Alpha diversity (Shannon index) and beta diversity (weighted UniFrac, principal coordinate analysis [PcoA]) were analyzed using QIIME [78]. LEfSe analyses were performed using an online LEfSe tool (http://huttenhower.sph.harvard.edu/galaxy) [79]. A heatmap of Spearman's rank correlation coefficients (regarding the relative abundances of the bacteria genera in all samples) was constructed using the corrplot package in $\mathrm{R}$.

\section{Colony-forming unit assays of Serratia sp. in M. alternatus midgut}

The relative abundances of Serratia sp. in the midgut of $M$. alternatus instars $\mathrm{I}-\mathrm{V}$ were analyzed by counting the colony-forming units $[28,80]$. The instars were reared on an artificial diet (wheat bran $60 \mathrm{~g}$, shrimp shell powder $10 \mathrm{~g}$, sorbate $2 \mathrm{~g}$, sodium benzoate $4 \mathrm{~g}$, yeast $25 \mathrm{~g}$, agar $30 \mathrm{~g}$, phloem powder $100 \mathrm{~g}$, xylem powder $50 \mathrm{~g}$, sucrose $40 \mathrm{~g}$, and water $300 \mathrm{~mL}$ ) and the second generation of larvae were used for the experiments. Additionally, wild-caught instars I-V were collected from the abovementioned pine stand. There were 10 replicates for each instar in the artificial diet and wild-caught groups. 16S rDNA sequencing and physiological and biochemical analysis indicated that the Serratia sp. in the midgut of $M$. alternatus was $S$. marcescens. Each midgut sample was dissected under a stereoscopic microscope, homogenized in $100 \mu \mathrm{L}$ TE buffer for $3 \mathrm{~min}$, and stored on ice until use. The homogenate was diluted with TE buffer and plated on Serratia Differential Medium (HIMEDIA, India) and Luria-Bertani medium. Serratia Differential Medium was used to differentiate between $S$. marcescens, S. rubidaea, and S. liquefaciens, based on their ability to ferment L-arabinose and decarboxylate ornithine [81]. The data were organized using Microsoft Excel 2016 and potential significant differences were analyzed by Student's t-tests and analysis of variance (ANOVA) in SPSS 18.0. A $p$-value of $<0.05$ was considered statistically significant.

\section{Supplementary information}

Supplementary information accompanies this paper at https://doi.org/10. 1186/s12864-020-6718-6.

Additional file 1: Figure S1. Rarefaction curves analysis of samples from Monochamus alternatus and its habitat niche. Figure S2. Profiling barplot of bacterial phyla from Monochamus alternatus and its habitat niche. Figure S3. The tax tree of bacterial genera from infected Pinus massoniana. Figure S4. The tax tree of bacterial genera from Monochamus alternatus. Figure S5. The tax tree of bacterial genera in the process of instar II larvae of Monochamus alternatus feeding on the phloem. Figure S6. The tax tree of bacterial genera in the process of instar III larvae of Monochamus alternatus feeding on the xylem. Figure S7. The tax tree of bacterial genera in the process of Monochamus alternatus adults feeding on the bark. Figure S8. The heatmap of Spearman's rank correlation coefficients of bacterial genera.

\section{Abbreviations}

ANOVA: Analysis of variance; CTAB: Hexadecyl trimethyl ammonium bromide; EDTA: Ethylenediaminetetraacetic acid; LEfSe: Linear discriminant analysis effect size; NCBI: National Center for Biotechnology Information; 
OTU: Operational taxonomic unit; RDP: Ribosomal Database Project; SDS: Sodium dodecyl sulfate; TE: Tris-EDTA

\section{Acknowledgements}

We wish to thank Dr. Jianghua Sun from the Institute of Zoology (Chinese Academy of Sciences) for critical revision; Qilian Zheng from the Lianjiang Forestry Bureau for help with sample collection; and Feng Xia, Jingshu Li, Yan Fang, and Shaozhen Wang for help with rearing M. alternatus indoors.

\section{Authors' contributions}

SQW and FPZ contributed to the conception and design of the study; YJG, QNL and LYC obtained the metagenome samples; YJG, QNL, ESS, and ASZ performed the data analysis; YJG performed the Serratia sp. colony-forming unit assays; YJG, SQW, QNL, LYC, RCL, GHL, XH, RW and LX drafted the manuscript; and $Y J G, S Q W$, and RCL reviewed the manuscript. All authors read and approved the submitted version.

\section{Funding}

This work was supported by the National Key Research and Development Program (no. 2017YFD0600105); National Natural Science Foundation of China (no. 31601905, U1905201); Science Fund for Distinguished Young Scholars of Fujian Agriculture and Forestry University (no. xjq201614); China Postdoctoral Science Foundation (no. 2017 M612107); Science and Technology Program of Fujian Province (no. 2018 N5002); Forestry Science Research Project of Fujian Forestry Department (no. Minlinke (2017) 03); Forest Science Peak Project of College of Forestry, Fujian Agriculture and Forestry University (no. 71201800720, 71201800753, and 71201800779); and Undergraduate Training Program for Innovation and Entrepreneurship of China (no. 201910389009).

\section{Availability of data and materials}

All raw sequences were deposited in the National Center for Biotechnology Information (NCBI) Sequence Read Archive (BioProject: PRJNA561715).

\section{Ethics approval and consent to participate}

There were no specific permits required for insect collection in the selected locations. The sampling locations are not privately owned or natural protected areas. The insects used for the experiments are not considered an endangered or protected species, and their collection is legal in China.

\section{Consent for publication}

Not applicable.

\section{Competing interests}

The authors declare that they have no competing interests.

\section{Author details}

'College of Forestry, Fujian Agriculture and Forestry University, Fuzhou 350000, China. ${ }^{2}$ Key Laboratory of Integrated Pest Management in Ecological Forests, Fujian Province University, Fujian Agriculture and Forestry University, Fuzhou 350000, China. ${ }^{3}$ State Key Laboratory of Ecological Pest Control for Fujian and Taiwan Crops, Fujian Agriculture and Forestry University, Fuzhou 350000, China. ${ }^{4}$ Universityof California, Irvine, CA 92697-4025, USA. ${ }^{5}$ Department of Microbiology \& Molecular Genetics, University of California, Irvine, CA 92697-4025, USA. ${ }^{6}$ Graduate School of Chinese Academy of Agricultural Sciences, Beijing 100081, China.

\section{Received: 24 August 2019 Accepted: 5 April 2020}

\section{Published online: 01 May 2020}

\section{References}

1. Proença DN, Grass G, Morais PV. Understanding pine wilt disease: roles of the pine endophytic bacteria and of the bacteria carried by the diseasecausing pinewood nematode. Microbiol Open 2017; 6(2):e415.

2. Ryss A, Vieira P, Mota M, Kulinich O. A synopsis of the genus Bursaphelenchus Fuchs, 1937 (Aphelenchida: Parasitaphelenchidae) with key to species. Nematology. 2005;7(3):393-458

3. Zhao LL, Mota M, Vieira P, Butcher RA, Sun JH. Interspecific communication between pinewood nematode, its insect vector, and associated microbes. Trends Parasitol. 2014;30(6):299-308
4. Mamiya Y, Shoji T. Pathogenicity of the pinewood nematode, Bursaphelenchus xylophilus, to Japanese larch, Larix kaempferi, seedlings. J Nematol. 2009;41(2):157-62.

5. Zhao BG. Pine Wilt Disease in China. In: Zhao BG, Futai K, Sutherland JR, Takeuchi Y, editors. Pine Wilt Disease. Tokyo: Springer; 2008.

6. Linit MJ. Nematode-vector relationships in the pine wilt disease system. J Nematol. 1988;20(2):227-35.

7. Bravo A. Phylogenetic relationships of Bacillus thuringiensis delta-endotoxin family proteins and their functional domains. J Bacteriol. 1997;179(9):2793-801.

8. Schnepf E, Crickmore N, Van RJ, Lereclus D, Baum J, Feitelson J, et al. Bacillus thuringiensis and its pesticidal crystal proteins. Microbiol Mol Biol Rev. 1998; 62(3):775-806

9. Crickmore N, Zeigler DR, Feitelson J, Schnepf E, Van RJ, Lereclus D, et al. Revision of the nomenclature for the Bacillus thuringiensis pesticidal crystal proteins. Microbiol Mol Biol Rev. 1998:62(3):807-13.

10. Crickmore $N$. The diversity of Bacillus thuringiensis $\delta$-endotoxins: Springer Netherlands; 2000.

11. Wang SB, Ghosh AK, Bongio N, Stebbings KA, Lampe DJ, Jacobs-Lorena M. Fighting malaria with engineered symbiotic bacteria from vector mosquitoes. Proc Natl Acad Sci. 2012;109(31):12734-9.

12. Wang SB, Dos-Santos ALA, Huang W, Liu KC, Oshaghi MA, Wei G, et al. Driving mosquito refractoriness to Plasmodium falciparum with engineered symbiotic bacteria. Science. 2017;357(6358):1399-402.

13. Müller DB, Vogel C, Bai Y, Vorholt JA. The plant microbiota: systems-level insights and perspectives. Annu Rev Genet. 2016:50(1):211-34.

14. Hannula SE, Zhu F, Heinen R, Bezemer TM. Foliar-feeding insects acquire microbiomes from the soil rather than the host plant. Nat Commun. 2019; 10:1254.

15. Leach JE, Triplett LR, Argueso CT, Trivedi P. Communication in the phytobiome. Cell. 2017;169(4):587-96.

16. Hu X, Li M, Raffa KF, Luo QY, Fu HJ, Wu S, et al. Bacterial communities associated with the pine wilt disease vector Monochamus alternatus (Coleoptera: Cerambycidae) during different larval instars. J Insect Sci. 2017; 17(6): 115

17. Vicente CSL, Nascimento FX, Margarida E, Pedro B, Koichi H, Manuel M, et al. Characterization of bacterial communities associated with the pine sawyer beetle Monochamus galloprovincialis, the insect vector of the pinewood nematode Bursaphelenchus xylophilus. FEMS Microbiol Lett. 2013:347(2):130-9.

18. Alves M, Pereira A, Matos P, Henriques J, Vicente C, Aikawa T, et al. Bacterial community associated to the pine wilt disease insect vectors Monochamus galloprovincialis and Monochamus alternatus. Sci Rep. 2016;6:23908.

19. Kawazu K, Zhang HH, Kanzaki H. Relationship between the pathogenicity of the pine wood nematode, Bursaphelenchus xylophilus, and phenylacetic acid production. Biosci Biotechnol Biochem. 1996;60(9):1413-5.

20. Kawazu K, Zhang H, Kanzaki H. Accumulation of benzoic acid in suspension cultured cells of Pinus thunbergii Parl. In response to phenylacetic acid administration. J Agric Chem Soc Jap. 1996:60(9):1410-2.

21. Wu XQ, Yuan WM, Tian XJ, Fan B, Fang X, Ye JR, et al. Specific and functional diversity of endophytic bacteria from pine wood nematode Bursaphelenchus xylophilus with different virulence. Int J Biol Sci. 2013;9(1):34-44.

22. Zhao BG, Lin F. Mutualistic symbiosis between Bursaphelenchus xylophilus and bacteria of the genus Pseudomonas. For Pathol. 2010;35(5):339-45.

23. Zhao BG, Wang HL, Han SF, Han ZM. Distribution and pathogenicity of bacteria species carried by Bursaphelenchus xylophilus in China. Nematology. 2003;5(6):899-906

24. Hyeokran K, Gyungja C, Yongho C, Kyoungsoo J, Nackdo S, Kang MS, et al Suppression of pine wilt disease by an antibacterial agent, oxolinic acid. J Nanjing Forest Univ. 2010;66(6):634-9.

25. Vicente CSL, Nascimento F, Espada M, Mota M, Oliveira S. Bacteria associated with the pinewood nematode Bursaphelenchus xylophilus collected in Portugal. Antonie Van Leeuwenhoek. 2011;100(3):477-81.

26. Vicente CSL, Nascimento F, Espada M, Barbosa P, Mota M, Glick BR, et al. Characterization of bacteria associated with pinewood nematode Bursaphelenchus xylophilus. PLoS One. 2012;7(10):e46661.

27. Proença DN, Francisco R, Santos CV, Lopes A, Fonseca L, Abrantes IMO, et al. Diversity of bacteria associated with Bursaphelenchus xylophilus and other nematodes isolated from pinus pinaster trees with pine wilt disease. PLoS One. 2010:5(12):e15191.

28. Proença DN, Francisco R, Kublik S, Schöler A, Vestergaard G, Schloter M, et al. The microbiome of endophytic, wood colonizing bacteria from pine trees as affected by pine wilt disease. Sci Rep. 2017;7(1):4205. 
29. Bal A, Anand R, Berge O, Chanway CP. Isolation and identification of diazotrophic bacteria from internal tissues of Pinus contorta and Thuja plicata. Can J For Res. 2012;42:807-13.

30. Pirttilä AM, Laukkanen $H$, Pospiech $H$, Myllylä R, Hohtola A. Detection of intracellular bacteria in the buds of scotch pine (Pinus sylvestris L.) by in situ hybridization. Appl Environ Microbiol. 2000;66(7):3073-7.

31. Strzelczyk E, Li CY. Bacterial endobionts in the big non-mycorrhizal roots of scots pine ( Pinus sylvestris L.). Microbiol Res. 2000;155(3):229-32.

32. Han ZM, Hong YD, Zhao BG. A study on pathogenicity of bacteria carried by pine wood nematodes. J Phytopathol. 2003;151(11-12):683-9.

33. Vicente CSL, Nascimento FX, Barbosa P, Ke H-M, Tsai IJ, Hirao T, et al. Evidence for an opportunistic and endophytic lifestyle of the Bursaphelenchus xylophilus-associated bacteria Serratia marcescens PWN146 isolated from wilting Pinus pinaster. Microb Ecol. 2016;72(3):669-81.

34. Alves $M$, Pereira A, Vicente C, Matos P, Henriques I. The role of bacteria in pine wilt disease: insights from microbiome analysis. FEMS Microbiol Ecol. 2018;94(7):fiy077.

35. Shi CE, Wang C, Xu XN, Huang B, Wu LM, Yang DX. Comparison of bacterial communities in soil between nematode-infected and nematode-uninfected Pinus massoniana pinewood forest. Appl Soil Ecol. 2015;85:11-20.

36. Jean C, Kuske C. Mobile genetic elements in the bacterial phylum Acidobacteria. Mob Genet Elem. 2012;2(4):179-83.

37. Janssen PH, Yates PS, Grinton BE, Taylor PM, Michelle S. Improved culturability of soil bacteria and isolation in pure culture of novel members of the divisions Acidobacteria, Actinobacteria, Proteobacteria, and Verrucomicrobia. Appl Environ Microbiol. 2002;68(5):2391-6.

38. Zhang YG, Cong J, Lu H, Li GL, Qu YY, Su XJ, et al. Community structure and elevational diversity patterns of soil Acidobacteria. J Environ Sci. 2014;26(8): $1717-24$.

39. Jones RT, Robeson MS, Lauber CL, Hamady M, Knight R, Fierer N. A comprehensive survey of soil acidobacterial diversity using pyrosequencing and clone library analyses. ISME J. 2009;3(4):442-53.

40. Sait M, Davis KER, Janssen PH. Effect of $\mathrm{pH}$ on isolation and distribution of members of subdivision 1 of the phylum Acidobacteria occurring in soil. Colloids Surf B Biointerfaces. 2006;53(2):215-24.

41. Chu H, Fierer N, Lauber CL, Caporaso JG, Knight R, Grogan P. Soil bacterial diversity in the arctic is not fundamentally different from that found in other biomes. Environ Microbiol. 2010;12(11):2998-3006.

42. Wiltshire P, Werner D. Symbiosis of plants and microbes. J Ecol. 1994;82:985.

43. Schloter M, Wiehe W, Assmus B, Steindl H, Hartmann A. Root colonization of different plants by plant-growth-promoting Rhizobium leguminosarum bv. Trifolii R39 studied with monospecific polyclonal antisera. Appl Environ Microbiol. 1997;63(5):2038-46.

44. Antoun H, Beauchamp CJ, Goussard N, Chabot R, Lalande R: Potential of Rhizobium and Bradyrhizobium species as plant growth promoting rhizobacteria on non-legumes: Effect on radishes ( Raphanus sativus L.). In: Molecular Microbial Ecology of the Soil Developments in Plant and Soil Sciences. Edited by G. H, W.J. B, vol. 83. Springer, Dordrecht; 1998.

45. Coenye T, Vamme P. Diversity and significance of Burkholderia species occupying diverse ecological niches. Environ Microbiol. 2003;5(9):719-29.

46. Guo JK, Tang SR, Ju XH, Ding YZ, Liao SQ, Song NN. Effects of inoculation of a plant growth promoting rhizobacterium Burkholderia sp. D54 on plant growth and metal uptake by a hyperaccumulator Sedum alfredii Hance grown on multiple metal contaminated soil. World J Microbiol Biotechnol. 2011;27(12):2835-44

47. Ferrari B, Winsley T, Ji M, Neilan B. Insights into the distribution and abundance of the ubiquitous Candidatus Saccharibacteria phylum following tag pyrosequencing. Sci Rep. 2014;4(2):3957-66.

48. Soro V, Dutton LC, Sprague SV, Nobbs AH, Jenkinson HF. Axenic culture of a candidate division TM7 bacterium from the human oral cavity and biofilm interactions with other oral bacteria. Appl Environ Microbiol. 2014;80(20): 6480-9.

49. Nayak AS, Kumar SS, Kumar MS, Anjaneya O, Karegoudar TB. A catabolic pathway for the degradation of chrysene by Pseudoxanthomonas sp. PNK04. FEMS Microbiol Lett. 2011;320(2):128-34.

50. Kikuchi T, Jones JT, Aikawa T, Kosaka H, Ogura N. A family of glycosyl hydrolase family 45 cellulases from the pine wood nematode Bursaphelenchus xylophilus. FEBS Lett. 2004;572(1-3):201-5.

51. Proença DN, Fonseca L, Powers TO, Abrantes IMO, Morais PV. Diversity of bacteria carried by pinewood nematode in USA and phylogenetic comparison with isolates from other countries. PLoS One. 2014;9:e105190.
52. Choi MY, Ahn JH, Song J, Kim SH, Bae JW, Weon HY. Analysis of gut bacterial diversity and exploration of cellulose-degrading bacteria in xylophagous insects. Kor J Microbiol. 2015;51(3):209-20.

53. Hao F, Lv WY, Huang Z, Liu SJ, Yang H. Gryllotalpicola reticulitermitis sp. nov., isolated from a termite gut. Int J Syst Evol Microbiol. 2015;65(Pt 1):85-9.

54. Peterson BF, Stewart HL, Scharf ME. Quantification of symbiotic contributions to lower termite lignocellulose digestion using antimicrobial treatments. Insect Biochem Mol Biol. 2015;59:80-8.

55. RiazulHaq SAR. Microorganisms resistant to heavy metals and toxic chemicals as indicators of environmental pollution and their use in bioremediation. Folia Biol. 2000;48(3-4):143-7.

56. Djukic D, Mandic L. Microorganisms as indicators of soil pollution with heavy metals. Acta Agric Serbica. 2006;22:45-55.

57. Tian XL, Zhang QL, Chen GH, Mao ZC, Xie BY. Diversity of bacteria associated with pine wood nematode revealed by metagenome. Acta Microbiol Sin. 2010;50(7):909-16.

58. Anand AAP, Vennison SJ, Sankar SG, Prabhu DIG, Vasan PT, Raghuraman T, et al. Isolation and characterization of bacteria from the gut of Bombyx mori that degrade cellulose, xylan, pectin and starch and their impact on digestion. J Insect Sci. 2010;10(2):107.

59. Grimont F, Grimont PAD. The genus Serratia. Annu Rev Microbiol. 2006; 32(1):221-48.

60. Zhang Q, Melcher U, Zhou L, Najar FZ, Roe BA, Fletcher J. Genomic comparison of plant pathogenic and nonpathogenic Serratia marcescens strains by suppressive subtractive sybridization. Appl Environ Microbiol. 2005;71(12):7716-23.

61. Dong R, Gu LJ, Guo CH, Xun FF, Liu JL. Effect of PGPR Serratia marcescens $\mathrm{BC}-3$ and AMF Glomus intraradices on phytoremediation of petroleum contaminated soil. Ecotoxicology. 2014;23:674-80.

62. Paiva G, Proença DN, Francisco R, Verissimo P, Santos SS, Fonseca L, et al. Nematicidal bacteria associated to pinewood nematode produce extracellular proteases. PLoS One. 2013;8(11):e79705.

63. Hu X, Yu JM, Wang CY, Chen H. Cellulolytic bacteria associated with the gut of Dendroctonus armandi Larvae (Coleoptera: Curculionidae: Scolytinae). Forests. 2014:5:455-65.

64. Hu X, Fu HJ, Li JN, Lin ZP, Zhang FP. Isolation and identification of cellulolytic bacteria associated with the gut of Monochamus alternatus larvae. J Fujian Agric Forestry Univ. 2018:47:322-8.

65. Medie FM, Davies GJ, Drancourt M, Henrissat B. Genome analyses highlight the different biological roles of cellulases. Nat Rev Microbiol. 2012;10(3):22734.

66. Watanabe H, Tokuda G. Cellulolytic systems in insects. Annu Rev Entomol. 2010;55:609-32.

67. Cano-Ramírez C, Santiago-Hernández A, Rivera-Orduña FN, García-Huante Y, Zúñiga G, Hidalgo-Lara ME. Expression, purification and characterization of an endoglucanase from Serratia proteamaculans CDBB-1961, isolated from the gut of Dendroctonus adjunctus (Coleoptera: Scolytinae). AMB Express. 2016;6(1):63.

68. Proença DN, Espirito SC, Grass G, Morais PV. Draft genome sequence of Serratia sp. strain M24T3, isolated from pinewood disease nematode Bursaphelenchus xylophilus. J Bacteriol. 2012;194(14):3764.

69. Cheng XY, Tian XL, Wang YS, Lin RM, Mao ZC, Chen NS, et al. Metagenomic analysis of the pinewood nematode microbiome reveals a symbiotic relationship critical for xenobiotics degradation. Sci Rep. 2013;3:1869.

70. Perestelo F, Falcón MA, Carnicero A, Rodrfguez A. Fuente' dIG. Limited degradation of industrial, synthetic and natural lignins by Serratia marcescens. Biotechnol Lett. 1994;16(3):299-302.

71. Matsunaga K, Togashi K. A simple method for discriminating Bursaphelenchus xylophilus and B. mucronatus by species-specific polymerase chain reaction primer pairs. Nematology. 2004;6:273-7.

72. Togashi K. Different developments of overwintered larvae of Monochamus alternatus (Coleoptera: Cerambycidae) under a constant temperature. Jap J Entomol. 1991;59:149-54.

73. Togashi K. Effects of photoperiod and chilling on diapause induction, intensity and termination in Monochamus alternatus endai (Coleoptera: (erambycidae). J For Res. 2019;24:243-9.

74. Zhou J. DNA recovery from soils of diverse composition. Appl Environ Microbiol. 1996;62(2):316-22.

75. Masella AP, Andrea KB, Jakub MT, Daniel GB, Josh DN. PANDAseq: pairedend assembler for illumina sequences. BMC Bioinformatics. 2012;13(1):31.

76. Edgar RC. UPARSE: highly accurate OTU sequences from microbial amplicon reads. Nat Methods. 2013;10(10):996. 
77. Cole JR, Chai B, Farris RJ, Wang Q, Kulam SA, D M McGarrell et al. The ribosomal database project (RDP-III): sequences and tools for highthroughput rRNA analysis. Nucleic Acids Res 2005; 33:D294-D296.

78. Caporaso JG, Justin K, Jesse S, Kyle B, Frederic DB, Elizabeth KC, et al. QIIME allows analysis of high-throughput community sequencing data. Nat Methods. 2010;7:335-6.

79. Nicola S, Jacques I, Levi W, Dirk G. Metagenomic biomarker discovery and explanation. Genome Biol. 2011;12(6):R60.

80. Wang XM, Liu T, Wu Y, Zhong DB, Zhou GF, Su XH, et al. Bacterial microbiota assemblage in Aedes albopictus mosquitoes and its impacts on larval development. Mol Ecol. 2018;27:2972-85.

81. MacFaddin JF. Media for Isolation-Cultivation-Identification-Maintenance of Medical Bacteria, Vol. I, vol. 1. Baltimore: Williams and Wilkins; 1985.

\section{Publisher's Note}

Springer Nature remains neutral with regard to jurisdictional claims in published maps and institutional affiliations.

Ready to submit your research? Choose BMC and benefit from:

- fast, convenient online submission

- thorough peer review by experienced researchers in your field

- rapid publication on acceptance

- support for research data, including large and complex data types

- gold Open Access which fosters wider collaboration and increased citations

- maximum visibility for your research: over $100 \mathrm{M}$ website views per year

At $\mathrm{BMC}$, research is always in progress.

Learn more biomedcentral.com/submissions 